\title{
The Effects of Product Quality and Interpersonal Communication on Customer Loyalty
}

\author{
Muhammad Tafsir ${ }^{* 1}$, Roziana Shaari ${ }^{2}$, Hasyim Muchtar ${ }^{3}$, Firmansya $^{4}$ \\ 1,3,4 Management Department, STIEM Bongaya, Makassar, 90224, Indonesia \\ *e-mail: tafsirmuhammad@yahoo.com \\ ${ }^{2}$ Department of Human Research, Faculty of Management, \\ Universiti Teknologi Malaysia
}

\begin{abstract}
The rapid development of the business world today makes more and more companies are innovating the products sold, services provided and provide appropriate information to their customers to create a loyal consumer of the company. The purpose of this research is to analyze the effect of product quality, and interpersonal communication to consumer loyalty. The research method used is Simple Random Sampling with multiple linear regression analysis techniques. To ensure the accuracy of information, the number of population as much as 524 people are then drawn the number of samples as many as 100 people. The results showed that based on a simultaneous test ( $\mathrm{F}$ test), product quality and interpersonal communication had the positive and significant effect to consumer loyalty but based on a partial test (t-test) there are different results where only interpersonal communication does not affect consumer loyalty. Interpersonal communication is not very influential on consumer loyalty and most importantly for consumers is the fulfillment of banking needs can be met without the presence of perceived difficulty.
\end{abstract}

Keywords - Product quality; interpersonal communication; consumer

\section{INTRODUCTION}

The rapid development of the business world today makes more companies emerging. Thus, the higher the level of competition against existing and emerging companies. Various innovations arise made by new companies such as improving product quality, service quality and providing information through good communication so that all information related to products and services can be appropriately delivered. This is done to seize the existing market share and switch to using products from the new company. Of course, this is a threat as well as a future challenge for existing companies and already have customers.

Competition is also not free from the banking world today. The banks are competing to create various innovations to their products and provide the maximum possible information to consumers [1]. Accordingly, the consumer loyalty can be maintained [2]. Talking about product quality, consumers put high expectations on the products used to help to overcome the economic activities both regarding commercial traffic and the fulfillment of the need for additional financing of the business to become more developed. Thus if expectations can be met then create loyalty to the product. 
The meaning of bank is defined by the Law of the Republic of Indonesia Number 10 of 1998 on banking (article 1, paragraph 2). A bank is a business entity that collects funds from the public in the form of savings and distributed to the community in the form of credit and or other forms with the aim of improving the standard of living of many people. The definition of a bank according to the Law of the Republic of Indonesia No 23 of 1999, a bank is a Commercial Bank and a Rural Bank (BPR) as referred to in the applicable law. The BPR is an official banking institution which is regulated under the Law Act No. 7 of 1992 concerning banking and as amended by Act No. 10 of 1998. The Act states that there are two types of banks, namely commercial banks and rural banks.

The consumer is a king means that she/he must be served with all they wish and need [3]. Service provided should be corresponding to serving a king in a sense still within the boundaries of ethics and morals by not degrading the degree of the bank or customer service. The arrival of the consumer to the bank is to realize the desire, whether in the form of information, application filling or complaints. Consequently, the duty of customer service officer is trying to meet the wishes and needs of consumers.

Product quality is the characteristic of a product or service that stand on its ability to satisfy stated or implied customer needs [4], [1]. The product quality is a character preserved by a product that can meet customer needs. Product quality is the ability of a product in demonstrating its function; it includes overall durability, reliability, accuracy, ease of operation and reparation products as well as other product attributes. Compatibility in the use of a product is if the product has the extended durability of use, the product used can improve the image or the status of consumers who use it. The product is not easily damaged, the existence of quality assurance and appropriate ethics when used.

Good interpersonal relationships characterize effective communication. The failure of subsequent communication occurs when the content of the message is understood, but the relationship between the communicants becomes damaged. Effective interpersonal communication encompasses many elements, but interpersonal relationships are perhaps the most important [5]. To grow and improve interpersonal relationships require improving the quality of communication. Some factors that influence interpersonal communication supported behavior and open attitude [6]-[8], Interpersonal Communication Effectiveness begins with five general qualities considered openness, empathy, supportiveness, positiveness, equality [9].

Loyalty is a firmly held commitment to buy back or subscribe to a product of choice or service in the future even though situational influences and marketing efforts have the potential to cause consumers to switch to other products [10], [1]. The success or failure of a company in creating loyal customers depends desperately on the company's ability to create value and continuously strives to improve it. The rewards of loyalty are long-term and cumulative. As an effort to get loyal customers, the company must develop a more accurate strategy, among them is to improve the quality of service and product quality and to know the position of competitors and estimate the amount of market share.Based on the conceptual research, the proposed three 
hypotheses. The first hypothesis is the product quality has the positive and significant effect on consumer loyalty. The second hypothesis is interpersonal communication has a positive and significant impact on consumer loyalty. The third hypothesis is product quality and interpersonal communication have a positive and significant impact on consumer loyalty.

\section{METHOD}

This research is quantitative research based on the philosophy of positivism, used to examine in a particular population or sample [11]. This research method used random sampling technique with multiple linear regression analysis. Data were collected using questionnaire instrument. The population of this research is the total of 524 people (data per July 2017). The number of the sample determined using the Krejcie and Morgan method to obtain a sample of 226 people [12]. The analytical method was used for validity test and reliability, multicollinearity test, multiple linear regression analysis, and hypothesis test consist of F-test and t-test [13], [14].

\section{RESULTS}

\section{A. Multicollinearity Test}

Multicollinearity test results also aim to test whether the regression model found a correlation between independent variables. A good regression model should not be a correlation between independent variables, because if they occur, then they are not orthogonal or similar. If the tolerance value is higher than 0.10 or VIF less than 10 it can be concluded that there is no multicollinearity. Based on Coefficients in the Table I indicates that the VIF value is 1.662 (Product Quality Variables) and 1.616 (Interpersonal Communication Variables). This result means that the variable is free from the classical assumptions of Multicollinearity, the result is less than 10 . Multiple regression analysis is used to predict the magnitude of the effect of product quality variables, service quality and interpersonal communication to consumer loyalty. From the calculation results obtained by regression equation as follows:

TABLE I

RESUlt OF MULTICOLINEARITY TEST

\begin{tabular}{lll}
\hline \hline & \multicolumn{2}{l}{ Collinearity Statistics } \\
\hline Model & Tolerance & VIF \\
\hline (Constant) & & \\
Product Quality & .602 & 1.662 \\
Interpersonal Communication & .619 & 1.616 \\
\hline \hline
\end{tabular}

Based on Coefficients in the above table, it is known that the VIF value is 1.662 (Product Quality Variables) and 1.616 (Interpersonal Communication 
Variables). This result means that the variable is free from the classical assumptions of multicollinearity, the result is less than 10 .

B. Multiple Linear Regression Test

Multiple regression analysis is used to predict the magnitude of the effect of product quality variables and interpersonal communication to consumer loyalty. From the calculation results obtained by regression equation as follows:

TABLE II

COEFFICIENT ANALYSIS OF MULTIPLE LINEAR REGRESSION ON EQUATION ANALYSIS

\begin{tabular}{|c|c|c|c|c|c|}
\hline & \multicolumn{2}{|c|}{$\begin{array}{l}\text { Unstandardized } \\
\text { Coefficients }\end{array}$} & \multicolumn{2}{|c|}{$\begin{array}{l}\text { Standardized } \\
\text { Coefficient }\end{array}$} & \multirow[b]{2}{*}{$\mathrm{Sig}$} \\
\hline & B & Std Error & Beta & $\mathrm{t}$ & \\
\hline 1 (Constant) & .155 & 2.674 & & .043 & .966 \\
\hline $\begin{array}{l}\text { Product Quality } \\
\text { Interpersonal }\end{array}$ & .382 & .068 & .432 & 5.572 & .000 \\
\hline Communication & .098 & .067 & .112 & 1.470 & .145 \\
\hline
\end{tabular}

a. Dependent Variable : Consumer Loyalty

Based on Table II above on the results of multiple linear regression coefficients, the regression equation is as follows:

$$
Y=0.115+0.382 x 1+0.0982 \times 2
$$

C. Coefficient of Determination Analysis $\left(R^{2}\right)$

The analysis of coefficient of determination $\left(\mathrm{R}^{2}\right)$ or R-Square is used to compute how much independent variable can explain dependent variable. In other words, the determinant coefficient is used to measure an independent variable that is product quality (X1), and interpersonal communication (X2) explain dependent variable that is loyalty consumer. The SPSS input for the coefficient of determination can be seen in the table as follows:

TABLE III

MODEL SUMMARY

\begin{tabular}{cccc}
\hline \hline $\mathrm{R}$ & $\mathrm{R}$ Square & $\begin{array}{c}\text { Adjusted R } \\
\text { Square }\end{array}$ & $\begin{array}{c}\text { R Square } \\
\text { Change }\end{array}$ \\
\hline & & & \\
$.808^{\mathrm{a}}$ & .652 & .641 & .652 \\
\hline \hline
\end{tabular}

a. Predictors: (Constant), Interpersonal communication, Quality product,

b. Dependent Variable: Customer loyalty

The value of $\mathrm{R}$ describes the type of relationship between variables. The higher the value of $\mathrm{R}$ the closer the relationship. $\mathrm{R}$-value of 0.808 means the relationship (relation) between product quality and interpersonal communication to consumer loyalty of $80.8 \%$ means there is a close 
relationship. Correlation coefficient studied is at the coefficient interval of 0.70 to 0.89 with the level solid relationship [15] Given the value of the coefficient of determination $\left(\mathrm{R}^{2}\right)$ of 0.652 indicates that product quality and interpersonal communication as an independent variable able to explain loyalty as a dependent variable of $65.2 \%$. This shows that consumer loyalty is not only influenced by product quality and interpersonal communication, but there are still some other factors that influence consumer loyalty and not found in this research that is equal to $34.8 \%$.

\section{Hypothesis testing}

Hypothesis testing is done together (simultaneously) and partially. The effect of independent variable on the dependent variable is tested with $95 \%$ confidence level or $\alpha=5 \%$. The test was performed using SPSS. F-Test is performed to test whether the product quality and interpersonal communication variables simultaneously or simultaneously have a significant influence on consumer loyalty. Hypothesis testing is done by comparing the value of $\mathrm{F}$ arithmetic with the value of $\mathrm{F}$ Table with the criteria is if $\mathrm{F}$ arithmetic $<\mathrm{F}$ table then $\mathrm{H}_{0}$ accepted, and $\mathrm{H}_{1}$ rejected, but if $\mathrm{F}$ arithmetic $>\mathrm{F}$ table, then $\mathrm{H}_{0}$ rejected and $\mathrm{H}_{1}$ accepted.

\section{1) The effect of product quality (X1) on consumer loyalty $(Y)$.}

In coefficients model, it indicates the Sig value. 0.000 is smaller than probability 0.05 or value $0.000<0.05$ then $\mathrm{H} 0$ is rejected, and $\mathrm{H} 1$ accepted. Product quality variables have t-count 5.572 to t-table 1.985 . Thus, $t$-count $>$ t-table. Thus, it can be concluded that product quality has a significant effect on consumer loyalty. A positive value indicates that the variable of product quality has a relationship that is in line with consumer loyalty with a value of the beta coefficient of product quality variable (X1) is 0.432 . This shows the effect of product quality variable to consumer loyalty is $43,2 \%$.

\section{2) The Effect of Interpersonal Communication (X2) on Consumer Loyalty (Y).}

In coefficients model also indicates a Sig value. 0.145, greater than probability 0.05 or value $0.145>0.05$ then $\mathrm{H} 0$ is accepted, and $\mathrm{H} 1$ is rejected. Interpersonal communication variables have t-count of 1.470 with $\mathrm{t}$ table 1.985 so t-count $<\mathrm{t}$-table. Thus, it can be concluded that interpersonal communication does not affect consumer loyalty. This shows that the interpersonal communication variables have a relationship that is not in line with consumer loyalty. Consequently, it can be concluded interpersonal communication does not affect consumer loyalty. The beta coefficient of interpersonal communication variable $(\mathrm{X} 2)$ is 0.112 . It shows that the influence of interpersonal communication variable to consumer loyalty is $11,2 \%$.

From the description above can be seen that the most dominant influence on product quality variables and interpersonal communication to consumer loyalty is the product quality shown by the largest beta coefficient value is 0.432 . From this result, it can be concluded that product quality variable has bigger influence on consumer loyalty.

\footnotetext{
IJoASER, Volume 1, Issue 1, March 2018

DOI: 10.33648/ijoaser.v1i1.1

Copyright: STAI Al-Furqan Makassar,Indonesia

Content License: CC-BY-SA
} 


\section{DISCUSSION}

The discussion in this research is about the effect of product quality (X1) and interpersonal communication (X2) to consumer loyalty (Y). This section deals with three parts. The first part is the effect of Product Quality (X1) on Consumer Loyalty. The second part is the effect of Interpersonal Communication (X2) on Consumer Loyalty. The third part is the impact of Product Quality, and Interpersonal Communication (X3) on Consumer Loyalty.

\section{A. Hypothesis Testing 1: Effect of Product Quality (X1) on Consumer Loyalty}

Product quality variables are measured based on five construct indicators: product performance, product features, perfected capabilities, suitability and perceived quality. Each construct consisting of several indicators. The main benefits of the product shape product performance dimensions. The dimension of product features is formed by the choice or option for the consumer. Improved Traffic dimensions are formed by easy, fast and competent. The promise of the product shapes the dimensions of conformity. As well as the perceived quality dimension shaped by consumer ratings of image, brand or advertising. The result of the statistical analysis shows that product quality has a positive and significant effect on consumer loyalty with beta coefficient 0.432 and $\mathrm{p}$-value 0.000 (less than 0.05 ). therefore, analysis from this research model indicate that product quality increase if there is an improvement of consumer loyalty. This means the better the quality of the product given the consumer is more satisfied using the product and will be loyal. The results of this study are in line with previous research conducted about the effect of product quality on the satisfaction and loyalty of the customers of Telkom Flexi [16].

\section{B. Hypothesis Testing 2: The Effect of Interpersonal Communication (X2) on Consumer Loyalty}

Interpersonal communication variables are measured based on five constructive indicators: openness, empathy, supportive attitude, positive attitude and equality. However, there is usually a difference that occurs in the field where specifically for small and medium market segmentation, communication very rarely affects the success of a person to grow the loyal nature of a consumer. This is because the existing product and service system in this segment with existing middle and upper segments is much different. For small to medium-sized segments, typically the fulfillment of the need for fast products and services is paramount when compared to interpersonal communications run to negotiate to foster consumer loyalty. While for the middle and upper segments, negotiation is usually needed to influence a consumer to remain loyal to the products and services provided. Although in this case, the above five indicators have tried to run well that is already running openness, empathy, supportive attitude, positive attitude, and equality. However, for the consumer, the institution must understand the needs of products and services quickly as the priority of the leading choice. 
The result of the statistical analysis shows that interpersonal communication does not influence consumer loyalty with a beta coefficient value of 0.112 and p-value of 0.145 (greater than 0.05). Thus, the analysis of this model shows that interpersonal communication does not affect consumer loyalty. The results of this study contradict the research conducted by on the influence of services-cape and employee communication to customer loyalty through customer satisfaction at Bank Mandiri in Surabaya [17].

\section{Hypothesis Testing 3: The Impact of Product Quality, and Interpersonal Communication (X3) on Consumer Loyalty}

Based on the results of multiple linear regression analysis F-test showed 60.029 with 0.000 significance value. This study indicates that variable of product quality, service quality, and Interpersonal communication simultaneously has a significant effect on consumer loyalty. These results are in line with the results of research on the influence of product quality, service quality and interpersonal communication to customer loyalty at PT. Bank SulutGo Main Branch of Manado [18].

\section{CONCLUSION}

The quality of products partially has a significant impact on consumer loyalty influenced by the performance, feature, serviceability, conformity. Partial interpersonal communication does not affect consumer loyalty. The indicators are openness, empathy, supportiveness, positiveness, and equality. While in measurement simultaneously obtained product quality and interpersonal Communication simultaneously have the positive and significant influence on consumer loyalty. The indicators that affect the consumer is saying positive things, recommend to friends and make repurchase as well as a top choice.

All variables in this study that were tested simultaneously are product quality (X1) and interpersonal communication (X2) showed a significant impact on consumer loyalty. It is expected that all ranks of BPR Hasamitra Makassar branch can maintain the indicators of all the variables that exist now and if necessary more improved again in connection with the increasingly tight competition in the banking world today, but if tested in partial then only the interpersonal communication variables only that does not affect consumer loyalty. Nevertheless, our suggestion is still to be considered although the market segment faced is the middle to lower segment but communication remains an important thing to run as well as possible. It is necessary to have an organizational structure in each branch to further streamline the performance and coordination line between employees in branches and branches with the region because, in connection with the development of branch offices, the authority and responsibility should be given to the branch head. It is necessary to record the number of consumer complaints both in a month and a year as input material to the management to

\footnotetext{
IJoASER, Volume 1, Issue 1, March 2018

DOI: 10.33648/ijoaser.v1i1.1

Copyright: STAI Al-Furqan Makassar,Indonesia

Content License: CC-BY-SA
} 
make necessary improvements (as more real feedback from consumers).

\section{REFERENCES}

[1] J. F. Hair Jr, M. Wolfinbarger, A. H. Money, P. Samouel, and M. J. Page, Essentials of business research methods. Routledge, 2015.

[2] L. Aksoy, T. L. Keiningham, A. Buoye, B. Larivière, L. Williams, and I. Wilson, "Does loyalty span domains? Examining the relationship between consumer loyalty, other loyalties and happiness," J. Bus. Res., vol. 68, no. 12, pp. 2464-2476, 2015.

[3] R. E. Johnson, "Where Consumer Has Become King.," Trusteeship, vol. 6, no. 2, pp. 2629, 1998.

[4] G. Armstrong, S. Adam, S. Denize, and P. Kotler, Principles of marketing. Pearson Australia, 2014.

[5] M. N. Nasution, "Manajemen Pelayanan Terpadu edisi kedua," Jakarta Ghalia Indones., 2005.

[6] W. B. Gudykunst, S. Ting-Toomey, and E. Chua, Culture and interpersonal communication. Sage Publications, Inc, 1988.

[7] S. Trenholm and A. Jensen, Interpersonal communication. Oxford university press, USA, 2008.

[8] A. A. Berger, "Interpersonal communication," in Messages, Routledge, 2016, pp. 100117.

[9] A. D. Joseph, Human Communication: The Basic Course, Books a la Carte Edition. Prentice-Hall, Inc., 2017.

[10] K. L. Keller and P. Kotler, Marketing management. Pearson, 2016.

[11] B. C. Beins and M. A. McCarthy, Research Methods and Statistics. Pearson College Division, 2011.

[12] R. V Krejcie and D. W. Morgan, "Determining Sample Size for Research Activities," Educ. Psychol. Meas., vol. 30, no. 3, pp. 607-610, Sep. 1970.

[13] P. R. Hinton, I. McMurray, and C. Brownlow, SPSS Explained. Taylor \& Francis, 2014.

[14] S. Dowdy, S. Wearden, and D. Chilko, Statistics for Research. Wiley, 2011.

[15] P. R. Hinton, I. McMurray, and C. Brownlow, SPSS explained. Routledge, 2014.

[16] N. M. S. Wedarini, "Pengaruh Kualitas Produk Terhadap Kepuasan dan Loyalitas Pelanggan TELKOM FLEXI," E-Jurnal Manaj. Univ. Udayana; Vol 2 No 5, May 2013.

[17] M. Musriha, "Pengaruh Servicecape dan Kualitas Komunikasi Karyawan terhadap Loyalitas Nasabah melalui Kepuasan Nasabah Bank Mandiri di Surabaya," EKUITAS (Jurnal Ekon. dan Keuangan), vol. 15, no. 2, pp. 247-268, 2017.

[18] A. Novita, "Pengaruh Kualitas Produk, Kualitas Pelayanan, dan Komunikasi Interpersonal terhadap Loyalitas Nasabah pada PT. Bank Sulutgo Cabang Utama Manado,” J. Berk. Ilm. Efisiensi, vol. 16, no. 1, 2016. 